\title{
Editorial
}

\author{
Andrea Donatti Gallassi ${ }^{1}$ e Vagner dos Santos ${ }^{1,2}$
}

\section{A necessária e urgente mudança na abordagem das pessoas em sofrimento pelo uso de drogas}

O processo da reforma psiquiátrica brasileira trouxe no bojo de sua discussão a revisão dos modelos de atenção e gestão nas práticas de saúde mental, antes focados na figura do hospital psiquiátrico e nas práticas de isolamento e reclusão de pessoas em sofrimento psíquico, por ações de cuidado de base territorial e comunitária, promovendo uma organização em rede e náo apenas em um serviço ou equipamento. A construção dessa nova forma de abordagem do sofrimento mental teve por objetivo fazer face à complexidade das demandas de inclusão de pessoas secularmente estigmatizadas, com seus direitos humanos violados e à superação da violência asilar em um país de acentuadas desigualdades sociais como é o caso do Brasil. Ao longo desse processo de revisão da exclusão, do isolamento e da violência como formas de abordagem daqueles que sofrem por transtornos mentais, parece não terem sido devidamente incluídos no debate aqueles em sofrimento pelo uso de álcool e outras drogas, que se mantiveram à margem da discussão das políticas de saúde mental. Como consequência, suas demandas e necessidades acabaram por não ser propriamente incorporadas no âmbito da reforma psiquiátrica, deixando ser entendidas como questão, majoritariamente, de segurança pública e de justiça, o que perdura e tem efeitos até os dias de hoje.

Esse cenário de exclusão histórica e tímidas açóes no âmbito da saúde e do social fez com que o tema drogas e suas vulnerabilidades associadas passassem a constituir demanda de segurança pública e, portanto, passível do uso da força policial e da repressão como mecanismos de abordagem e controle; e quando tenta-se abordar o tema sob a perspectiva da saúde e da prevenção, muito frequentemente utiliza-se da "pedagogia do terror" para tratar do assunto, o que comprovadamente, além de não apresentar a efetividade desejada, afasta e dificulta o acesso das pessoas em sofrimento a reais possibilidades de ajuda. No esforço de recuperar o atraso histórico na abordagem do tema, mas principalmente com o objetivo de dar respostas a uma classe média incomodada com a questão, o governo federal lançou em 2012 o programa Crack, é possivel vencer (BRASIL, 2012), que tem como um de seus objetivos expandir a rede de atenção psicossocial para usuários de álcool e outras drogas. Embora bastante criticado pelo fato de ser um programa de governo focado em apenas uma droga - o crack -, a expansão da rede de cuidados beneficia todos que dela necessitam e não somente aquele com problemas relacionados ao uso dessa ou daquela substância.

Porém a expansão da rede de atenção prevista no programa Crack, É Possivel Vencer não se restringiu àquela da abordagem psicossocial, composta por equipamentos de base territorial e comunitária, um dos pressupostos da reforma psiquiátrica, a expansão também se deu na modalidade de intervenção que reproduz o modelo combatido de instituição total, como o que ocorre nas comunidades terapêuticas, no qual se centraliza o tratamento em espaços fechados de internação, sem articulação com outros serviços e tendo a abstinência como meta única.

Nesse sentido, é possível considerar que enfrentamos no Brasil, atualmente, pelo menos dois grandes desafios relacionados ao tema drogas: o recrudescimento das abordagens terapêuticas centradas na internação, reclusão e exclusão dos usuários de drogas; e a falta de conhecimento técnico-científico dos profissionais, à luz das melhores evidências no que se refere ao cuidado de pessoas em sofrimento pelo uso de drogas.

No âmbito da Terapia Ocupacional, esses desafios estão postos da mesma forma. Os estruturais também estão reconhecidos como dimensão válida e necessária da ação profissional, que nos exige desenvolver

${ }^{1}$ Centro de Referência sobre Drogas e Vulnerabilidades Associadas - CRR, Curso de Terapia Ocupacional, Faculdade de Ceilândia - FCE, Universidade de Brasília - UnB, Brasil.

${ }^{2}$ PHOENIX Erasmus Mundus - Joint Doctoral Program on Dynamics of Health and Welfare. École des Hautes Études en Sciences Sociales (France) \& Linköping University (Sweden). 
capacidades para participar, mudar e influenciar nos processos políticos e institucionais (POLLARD; SAKELLARIOU; KRONENBERG, 2008).

Adicionalmente, enfrentamos os desafios conceituais que orientam a prática, nossas concepçôes de saúde, de "normal", de ocupação, dentre outras. Por exemplo, questiona-se o fato de considerar ou não o uso de drogas como uma ocupação humana (KIEPEK; MAGALHÁES, 2011), uma vez que tratar-se-ia de uma ocupação náo saudável, em alguns contextos, confrontando, de certa forma, o entendimento de ocupação como algo que compóe o rol de atividades do ser humano e, portanto, aquilo que produz vida e funcionalidade. Por outro lado, considerando o conceito de ocupaçáo como qualquer coisa em que as pessoas se ocupam (CANADIAN..., 2008), o uso de drogas pode ser sim categorizado como ocupação e, portanto, necessário de ser compreendido à partir do contexto de onde ocorre e de quem a executa.

A intervenção do terapeuta ocupacional e de outros profissionais junto a usuários de drogas, muitas vezes, reproduz o que as políticas de massa insistem em propagar, que é ter a abstinência total como única possibilidade a ser atingida pelo tratamento, procurando fazer com que a droga desapareça do discurso e da vida de seus usuários. Sendo o cotidiano e o contexto recursos do terapeuta ocupacional e sendo ambos parte inerente do cenário de uso de drogas, a abordagem desses sujeitos deverá, inexoravelmente, considerar a droga como parte integrante do processo de cuidado e intervençáo, tanto presente no discurso quanto no próprio uso. A compreensão do uso de drogas como parte do fazer desses sujeitos é o que possibilitará aproximar-se deles para ofertar cuidado, compreendendo o paradoxo, vivenciado por muitos, do desejo de interromper o uso ao mesmo tempo em que deseja fortemente usar a substância (SANTOS; SILVA, 2013).

Nesse contexto de reinvindicação da condição cidadã e autônoma, a Terapia Ocupacional, seja social ou da saúde, apresenta-se no sentido de discutir, propor e ampliar o repertório de intervençóes no território, buscando estabelecer vínculos ao longo do processo por meio de trabalho em equipe e, quando possível, interdisciplinar (MALFITANO; BIANCHI, 2013). Os desafios na vida social, psíquica e produtiva podem ser considerados como o grande foco de atuação da Terapia Ocupacional com pessoas em sofrimento pelo uso de drogas, uma vez que por meio da busca de possibilidades para a realizaçáo de atividades significativas se oportunizam a retomada de vivências abandonadas em função do uso como também novas descobertas e experimentaçôes.

O conhecimento técnico-científico sobre o tema, tanto no que se refere ao modelo de tratamento e intervenção quanto à formação do profissional, somado a uma postura acolhedora, guiada pelos princípios dos direitos humanos e da cidadania, são elementos que possibilitarão uma efetiva mudança na forma de compreender e abordar o tema drogas, sabidamente diverso, complexo e multifatorial (GALLASSI; SANTOS, 2013).

Com isso esperamos que esta edição especial oportunize aos leitores uma vivência intensa sobre as diferentes formas e possibilidades de considerar o sofrimento pelo uso de drogas, tendo como perspectiva o abandono da supremacia da abstinência e das formas autoritárias, morais e punitivas de intervenção em favor de abordagens que elevem a condição de sujeito merecedor de cuidados destituídos de valores morais e conceitos que firam seu direito cidadão a um tratamento digno, em liberdade e em consonância com seus anseios e desejos.

\section{Referências}

BRASIL. Crack, épossivel vencer. Brasília, 2012. Disponível em: <http://www2.brasil.gov.br/crackepossivelvencer/ homes.

CANADIAN ASSOCIATION OF OCCUPATIONAL THERAPISTS - CAOT. CAOT position statement: occupations and health. Occupational Therapy Now, Ottawa, v. 11, n. 1, p. 24-26, 2008.

GALLASSI, A. D.; SANTOS, V. dos. O abuso de drogas: desafios e opções para a prática do profissional no Brasil. Brasilia Médica, Brasilia, v. 50, n. 1, p. 51-57, 2013.

KIEPEK, N.; MAGALHÂES, L. Addictions and impulsecontrol disorders as occupation: a selected literature review and synthesis. Journal of Occupational Science, Sidney, v. 18, n. 3, p. 254-276, 2011.
MALFITANO, A. P. S.; BIANCHI, P. C. Terapia ocupacional e atuação em contextos de vulnerabilidade social: distinçóes e proximidades entre a área social e o campo de atenção básica em saúde. Cadernos de Terapia Ocupacional da UFSCar, São Carlos, v. 21, n. 3, p. 563-574, 2013.

POLLARD, N.; SAKELLARIOU, D.; KRONENBERG, F. A political practice of occupational therapy. Edinburgh: Churchill Livingstone, 2008.

SANTOS, V; SILVA, G. G. Terapia Ocupacional na abordagem da dependência química. In: FERNANDES, S. et al. Abordagem multidisciplinar da dependência química. São Paulo: Santos, 2013. p. 151-158. 


\title{
Editorial
}

\author{
Andrea Donatti Gallassi ${ }^{1}$ e Vagner dos Santos ${ }^{1,2}$
}

\section{The necessary and urgent changing in the approach toward people in suffering by drug use}

\begin{abstract}
The process of the Brazilian Psychiatric Reform initiated a fundamental discussion and review of models and practices of mental health care and interventions in Brazil. Previously, most of these had relied on institutionalization, internment, and delivery of care by psychiatric hospitals, resulting in isolation and social exclusion of patients with mental health problems. These approaches were to be replaced or complemented by a range of community-based services and form a network of inpatient and outpatient interventions better suited for the needs of patients. This new approach to mental health care was to achieve improved social inclusion of people suffering from mental health conditions that had undergone stigma, human rights violations, and even institutional violence for a long time within the larger context of Brazil, a country marked by extensive social inequalities. Unfortunately, the population struggling with alcohol and/or drug use problems or addiction issues has not been fully included in the discussion and process of the Brazilian mental health care reform, because much of it lives and continues to exist at the margin of society. Instead, substance use or addiction issues continue to be largely seen and approached as public safety or justice - rather than health - issues so far.
\end{abstract}

The historical exclusion of drug users from the realms of social and health care and the primary reliance on tools of repression, criminalization and punishment has rendered drug users widely marginalized and has amplified their social and health vulnerabilities, while commonly barring them from access to adequate and required care. Some of these dynamics are exemplified in the federal government's program 'Crack - we can win' (BRASIL, 2012), chiefly a political driven response to the crack abuse problem in Brazil, accommodating middle class concerns about crack users as threats to public order and safety. One of the health-oriented benefits of the government's crack plan has been the expansion of networks of psycho-social care for alcohol and drug use across Brazil. While criticized for its singular focus on one drug type - crack - these services can provide benefits to users of all different kinds of substances.

However, the expansion of care services for drug use facilitated by the Crack plan was not restricted to the psycho-social and community-based care services - as encouraged by the principles behind the Brazilian Psychiatric Reform - yet helped to expand approaches of institutionalized therapeutic care regimes. Specifically, it supplied major resources to support treatment provided by 'Therapeutic Community'-based treatment centers, a treatment approach relying on long-term institutionalization of patients and the principal goal of abstinence, operating without integration or coordination with other assistance services.

Thus, it appears that we are currently facing two major challenges in regards to the issue of interventions for drug abuse in Brazil: First, a resurgence of therapeutic approaches relying on institutionalization, seclusion and social exclusion of drug users; and second, a lack of use and application of evidence-based technical knowledge for best practices in intervention and care for those suffering from drug use or addiction problems.

These challenges or concerns are shared from the perspective of the disciplinary domain of Occupational Therapy. Specifically, the structural challenges are recognized as valid and important, concretely resulting in the need to develop professional capacity and action to participate in, influence and change relevant political and institutional processes (POLLARD; SAKELLARIOU; KRONENBERG, 2008). Additionally, our discipline faces conceptual challenges that guide our understanding and practice related to occupational health as influenced by drug use and related issues (KIEPEK; MAGALHÃES, 2011). For example, the question arises whether drug use - as a commonplace human habit - principally and categorically influences occupational activities and related health in negative ways; in addition, there has been a longstanding debate whether drug use in itself may constitute a form of 'occupational activity', 
hence adding to human life and functionality (CANADIAN..., 2008). We believe the possibility for such consideration needs to be affirmed and supported, and constructively debated.

The engagement of occupational therapists and other professionals with drug users is commonly and strongly influenced by the ideology behind dominant policies, which - in concrete terms - promotes total abstinence as the fundamental goal of treatment and care and, therefore, seeks to eliminate drug use from the lives and existential discourses of drug users. Focusing on the everyday context and lifeworld of drug users' realities, the acceptance of the reality and existence of drug use in discourse and therapeutic practice ought to be possible and desirable within the professional practice of occupational therapy pertaining to drug use related intervention and care. Only when such acceptance occurs will it be possible for occupational therapy professionals to envisage and deliver care that is truly connected to and understanding of the often paradoxical life experiences of drug users that seek to quit their substance use while succumbing to urges and desires to continue their use (SANTOS; SILVA, 2013).

Also, in the context of increased attention given to values of individual citizenship and state of autonomy is the profession of occupational therapy - whether mainly focusing on social or health improvement - challenged with widening its repertoire of therapeutic measures in practice with the above goals in mind. Such an evolution of professional practice can be supported by an increasing reliance on interdisciplinary and/or teamwork practice (MALFITANO; BIANCHI, 2013). Occupational therapy practice should focus on helping individuals to meet the challenges of social and psychological health and functionality regardless of whether drug use occurs in their lives or not, and not make abstinence an a priori requirement for such experiences and accomplishments. In addition, experiences of social or occupational productivity need to be recognized as important steps in reducing the desire for or the negative consequences of drug use, and hence in the successful and sustained achievement of long-term recovery goals as assisted by occupational therapy interventions.

The evidence-based knowledge for good occupational therapy practice in both treatment and other care or support settings, coupled with a generally positive disposition - informed by principles of human rights and positive citizenship - that do not categorically dismiss the possibility of a healthy or productive existence in the context of drug use, are key elements for a progressive understanding and dealing with substance use issues, as notoriously complex and multifactorial these commonly are within the realms of occupational therapy practice (GALLASSI; SANTOS, 2013). With these principles and challenges in mind, we hope that the present Special Issue provides a welcome opportunity for its readers to gain new experiences and impressions about the experienced realities of drug use in different populations and settings, as well as informs the advancement of occupational therapy practice regarding drug use that is enabled to free itself from the categorical dominance of principles of abstinence, authority, and moralizing interventions; rather, we hope that the materials contained in this issue contribute to an increasingly enlightened occupational therapy practice aimed at substance use informed by principles of citizenship, human rights, and individual freedom combined towards the values of healthy life choices and productive existence.

\section{References}

BRASIL. Crack, é possivel vencer. Brasília, 2012. Disponível em: <http://www2.brasil.gov.br/crackepossivelvencer/ homes.

CANADIAN ASSOCIATION OF OCCUPATIONAL THERAPISTS - CAOT. CAOT position statement: occupations and health. Occupational Therapy Now, Ottawa, v. 11, n. 1, p. 24-26, 2008.

GALLASSI, A. D.; SANTOS, V. dos. O abuso de drogas: desafios e opçóes para a prática do profissional no Brasil. Brasília Médica, Brasilia, v. 50, n. 1, p. 51-57, 2013.

KIEPEK, N.; MAGALHÂES, L. Addictions and impulsecontrol disorders as occupation: a selected literature review and synthesis. Journal of Occupational Science, Sidney, v. 18, n. 3, p. 254-276, 2011.
MALFITANO, A. P. S.; BIANCHI, P. C. Terapia ocupacional e atuação em contextos de vulnerabilidade social: distinçóes e proximidades entre a área social e o campo de atenção básica em saúde. Cadernos de Terapia Ocupacional da UFSCar, São Carlos, v. 21, n. 3, p. 563-574, 2013. http://dx.doi.org/10.4322\%2Fcto.2013.058

POLLARD, N.; SAKELLARIOU, D.; KRONENBERG, F. A political practice of occupational therapy. Edinburgh: Churchill Livingstone, 2008.

SANTOS, V; SILVA, G. G. Terapia Ocupacional na abordagem da dependência química. In: FERNANDES, S. et al. Abordagem multidisciplinar da dependência química. São Paulo: Santos, 2013. p. 151-158. 